\title{
Franz Kafka, Fernando Pessoa e Mário de Andrade: o alcance das pequenas literaturas
}

\author{
Ana Lúcia Teixeira*
}

\section{Resumo}

Em seus diários, Franz Kafka formula a noção de pequena literatura, que servia para designar a produção de povos sem tradição literária. Nesse tipo de produção, Kafka percebeu a possibilidade de vocalizar uma cultura e contribuir para conferirIhe coesão social. Embora Kafka não tivesse em mente a sua própria produção quando cunhou o termo - o que gerou um debate acalorado que permanece aceso, sobretudo após Deleuze e Guattari publicarem, em 1975, um ensaio sobre o tema - o propósito deste artigo é o de averiguar em que medida o olhar de Kafka, como analista da cultura (aquele que formula a noção de pequena literatura), enxerga na literatura de seu tempo um conjunto de atributos que a apresentam como um intérprete e um ator social e político. $\mathrm{O}$ alcance analítico dessa categoria é examinado num trabalho comparativo com o olhar lançado por Fernando Pessoa e Mário de Andrade a seus respectivos contextos culturais, de forma a alargar a noção de pequena literatura formulada originalmente por Kafka.

Palavras-chave: Pequena literatura, Franz Kafka, Fernando Pessoa, Mário de Andrade, Literatura e política.

*Universidade Federal de São Paulo. São Paulo, SP, Brasil 


\section{Franz Kafka, Fernando Pessoa, and Mário de Andrade: the reach of minor literatures}

\section{Abstract}

In his diaries, Franz Kafka developed the notion of small literature, intended to mark out the production of nations with no literary tradition. Kafka perceived in this kind of production the possibility of vocalizing a culture and contributing to confer social cohesion on it. Although Kafka did not have his own production in mind when he coined the term - what generated a heated debate that persists, especially following an essay on the subject published by Deleuze and Guattari, in 1975 - the purpose of this article is to understand to what extent Kafka, as an analyst of culture (the one who elaborates the notion of small literature), detects in the literature of his time a set of attributes that characterize it as both an interpreter and a social and political actor. The analytical relevance of this category is examined through a comparative study involving the analyses of Fernando Pessoa and Mário de Andrade on their respective cultural contexts, in order to broaden the notion of minor literature originally developed by Kafka.

Keywords: Minor Literature, Franz Kafka, Fernando Pessoa, Mário de Andrade, Literature \& Politics.

Para Paulo, always

“- Eu sempre quis que vocês admirassem o meu jejum disse o artista da fome.

- Nós admiramos - retrucou o inspetor. - Por que não haveríamos de admirar?

- Mas não deviam admirar - disse o jejuador.

- Bem, então não admiramos - disse o inspetor. - Por que é que não devemos admirar?

- Porque eu preciso jejuar, não posso evitá-lo - disse o artista da fome.

- Bem se vê - disse o inspetor. - E por que não pode evitá-lo?

- Porque eu - disse o jejuador, levantando um pouco a cabecinha e falando dentro da orelha do inspetor com os lábios em ponta, como se fosse um beijo, para que nada se perdesse. - Porque eu não pude encontrar o alimento que me agrada. Se eu o tivesse encontrado, pode acreditar, não teria feito nenhum alarde e me empanturrado como você e todo mundo."

Franz Kafka, Um artista da fome, conto [1922] 1984. 
"Le romancier a I'oeil du prophète, non le regard du psychologue."

Gilles Deleuze, Critique et clinique, 1993

\section{De um insight, uma controvérsia}

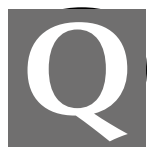

uando, em dezembro de 1911, Franz Kafka sentou-se à sua escrivaninha e derramou em seus diários seu entusiasmo pela dimensão política de um certo tipo de produção literária, formulou uma noção chave que geraria na fortuna crítica um debate acalorado que permanece aceso, especialmente no que se refere à pertinência de fazer incidir sobre sua própria produção uma reflexão que, em princípio, fora pensada a partir de produções oriundas de contextos culturais por ele denominados pequenos ${ }^{1}$. Partindo de suas impressões acerca da literatura tcheca, que ele próprio testemunha, e da literatura judaica produzida em Varsóvia, da qual lhe enviava notícias seu amigo Yitzchak Löwy (Kafka, [1911] 1971), Kafka elabora, naquele momento, a espinhosa noção de pequena literatura. O fio condutor de sua reflexão costura os atributos, a seu ver positivos, das literaturas produzidas pelo que ele denominou pequenos povos ou pequenas nações e sua inalienável dimensão política. O que o impressiona, especialmente, é a potencialidade intrínseca a essas literaturas para alcançar efeitos bastante contundentes fora do espaço estritamente literário, mesmo que ainda não houvessem adquirido um desenvolvimento excepcional. Dentre esses efeitos estão:

[...] o movimento dos espíritos, a união uniforme da consciência nacional, na vida exterior frequentemente inativa e sempre estilhaçada, o orgulho e o apoio que a nação recebe pela literatura, para si e frente ao entorno hostil, este manter diário de uma nação que é algo totalmente diferente do que historiografia e, em consequência, um mais rápido mas ainda assim sempre multiplamente revisto desenvolvimento, a detalhada espiritualização da ampla vida pública, a ligação de elementos insatisfeitos

${ }^{1}$ Cf. Deleuze e Guattari ([1975] 2014), Spector (2000), Dodd (2002), Casanova (2002; 2011), Zilcosky (2003), Corngold (2004), Thirouin (2007), Lecler (2013), Nekula (2016), entre outros. 
que aqui, onde dano só pode surgir pela negligência, tornam-se úteis imediatamente, o arranjo do povo que se forma pela azáfama das revistas e que sempre depende do todo, a restrição da atenção da nação a seu próprio círculo e acolhimento do estrangeiro só no espelhamento, o surgimento do respeito pelas pessoas literariamente ativas, o passageiro mas de efeito prolongado despertar de aspirações mais altas nas gerações novas, a assimilação de acontecimentos literários aos zelos políticos, o enobrecimento e a possibilidade de discussão da oposição entre pais e filhos, a apresentação dos erros nacionais numa maneira, sim, especialmente dolorosa, mas perdoável e libertadora, o surgimento de um vivo e por isso autoconfiante comércio livreiro e da avidez de livros [...] (Kafka, 1997, p. 196-7)².

Ressaltando a força criadora que irradia das condições circundantes dessa forma de produção literária, Kafka considera que "a vivacidade de uma literatura assim é até maior do que aquela de uma literatura rica em talentos, pois já que aqui não há escritores diante do dom dos quais pelo menos a maioria dos céticos teria de se calar, a querela literária na mais ampla escala ganha uma real justificativa" (Kafka, 1997, p. 197), e, nesse sentido, opera uma certa inversão que situa a força dessas literaturas precisamente em sua fragilidade.

Analisando a obra de Kafka e buscando dar consistência conceitual à noção kafkiana de pequena literatura, Gilles Deleuze e Félix Guattari exploram o potencial político de literaturas produzidas nessas condições, em uma análise muitíssimo contestada pela crítica posterior. A começar pela tradução equivocada do termo kleine Literaturen, no original (cf. Kafka, 1997, p. 205), que os autores, assumindo a tradução feita por Marthe Robert em 1954, tomam por literaturas menores. Para Pascale Casanova (2002, p. 250-1), Stanley Corngold (2004, p.274-5), Marie-Odile Thirouin (2007, p. 301-2) e Éric Lecler (2013, p. 200-1), não se trata de um simples equívoco de tradução, mas da adequação um tanto artificiosa do termo a uma problemática muito mais deleuze-guattariana do que propriamente kafkiana.

A crítica de Casanova aos autores refere-se, precisamente, à formulação da dimensão política que Deleuze e Guattari decorrem da obra

${ }^{2}$ Agradeço imensamente a Markus Lasch a tradução inédita para o português dos trechos originais do diário de Franz Kafka, a leitura atenta e cuidadosa deste artigo, assim como as questões que manterão acesas as motivações para escrevê-lo. 
de Kafka, a qual se constitui em termos demasiado abstratos e anacrônicos em relação ao contexto em que Kafka viveu, uma vez que os casos são lidos na chave da subversão, que é, na verdade, um tema candente para a filosofia francesa da década de 1960. Nessa linha argumentativa, esses autores imputariam à perspectiva de Kafka um sentido genérico e descolado das lutas políticas efetivamente travadas na Praga de Kafka, o que, por consequência, reduziria toda especificidade das literaturas, em alguma medida envolvidas em problemas políticos específicos, a um denominador abstrato comum que em nada contribuiria para a compreensão dos problemas efetivos enfrentados em cada uma delas. Assim, Deleuze e Guattari apresentariam a figura de Kafka como "um autor político sem verdadeiras preocupações políticas, que não se preocuparia com as questões políticas candentes de seu tempo" (Casanova, 2002, p. 251), quando, na perspectiva de Casanova, a força política dessa literatura apreender-se-ia com maior eficácia precisamente pelo processo contrário, qual seja, do enraizamento desse autor e de sua literatura em um chão histórico muito específico, marcado por disputas políticas claramente definidas, em um espaço literário complexo e tripartido entre as culturas alemã, tcheca e judaica ${ }^{3}$.

O problema, no entanto, é de tamanha complexidade, que dois críticos diversos como Corngold e Lecler, ao criticarem a leitura de Deleuze e Guattari, acertam um ao outro no fogo cruzado, embora sequer sejam mencionados mutuamente. Por meio de uma análise cuidadosa da passagem do diário de Kafka, Corngold considera insustentável a tentativa de vincular o sintagma de pequena literatura à produção própria de Kafka, e, mais do que isso, de vincular a literatura de Kafka ao contexto político de Praga. Para ele, no afã de encontrar em Kafka seu anti-Édipo, Deleuze e Guattari descolar-se-iam do texto kafkiano e encontrariam na figura do autor uma espécie de herói revolucionário de uma nacionalidade tcheca ou judaica cujos idiomas ele sequer dominava -, criador de uma literatura fundamente marcada pelo manejo de um alemão supostamente entremeado pelo iídiche e pelo tcheco, o que parece ser uma flagrante "invenção" de Deleuze

3 Para mais detalhes veja Casanova, 2011, capítulo "L'espace littéraire". 
e Guattari. Isso resultaria de uma leitura equivocada, que encontra em Kafka o projeto de subverter o alemão, por uma espécie de mestiçagem revolucionária da língua, perspectiva que, por exemplo, "esforça-se, sem sucesso, por ignorar as influências escolhidas de Goethe, Hegel e Nietzsche, sem falar nas 'relações consanguíneas' com Kleist, Grillparzer, Dostoiévsky e Flaubert" (Corngold, 2004, p. 287). Trata-se, aqui, de advogar em favor da autonomia da literatura de Kafka em relação ao seu complexo contexto político e de posicioná-lo no seleto grupo de grandes autores europeus de língua alemã, como ele próprio pretendia estar.

Na contramão dessa perspectiva, Lecler localiza o trabalho de Deleuze e Guattari no cenário teórico na França dos anos 1960, argumentando que uma certa embocadura comum, que atravessa o estruturalismo, a semiótica e a linguística, constituiu o que ele chama de absoluto literário, cuja origem estaria situada nos trabalhos de Sartre, Barthes e Foucault e se projetaria sobre a obra de Kafka, a partir das análises de Maurice Blanchot (1981), Marthe Robert e, finalmente, Deleuze e Guattari. Tomada como pura idealidade transcendental, que escaparia a toda tentativa de formulação conceitual, a Literatura (com inicial maiúscula), como absoluto literário, é emoldurada em uma aura de sacralidade que a apresenta, por princípio, como inapreensível e problemática, tornando-se o objeto de uma certa teologia negativa. Em trabalhos pouco atentos às obras literárias e de fato interessados em exercitar o conceito de Literatura, esses autores colocariam essa idealidade absoluta no lugar da história e, dessa forma, apresentariam como única dimensão política da literatura aquela que se refere à "liberdade do homem que se põe como consciência crítica" (Lecler, 2013, p. 12). Tal perspectiva subtrairia da literatura toda sua ancoragem contextual e, dessa maneira, operaria uma espécie de solvência da singularidade das obras que, dessa forma, seriam transformadas em pretextos para uma discussão abstrata sobre a intransitividade da linguagem literária.

A despeito da natureza diversa dos problemas apontados por Casanova, Lecler, Corngold e Thirouin na análise realizada por Deleuze e Guattari, estão todos de acordo em que esses últimos autores promovem um 
encaixe artificioso da literatura e da figura de Kafka em seu próprio tema e, o que é mais importante para o meu argumento, que os autores franceses deslocam para a análise da obra de Kafka uma consideração que é feita por ele não acerca de sua própria produção, mas das literaturas tcheca e judaica. Aqui, é Marie-Odile Thirouin quem nos ajuda a compreender o problema, promovendo uma genealogia da expressão literatura menor, que Ihe permite pontuar a sequência de equívocos que teria dado origem a um conceito tão deficitário em relação ao texto kafkiano, o qual, justamente, pretendia caracterizar. O problema tem início já na primeira versão dos diários de Kafka, que vem a público em 1951, após algumas alterações promovidas por Max Brod. O amigo e depositário dos textos de Kafka compila as anotações feitas ao longo de três dias (25, 26 e 27 de dezembro de 1911) em um único texto que assumiria, assim, uma forma mais ensaística que, de forma alguma, teria sido pretendida por Kafka. Em segundo lugar, Brod, que teve uma atuação militante em prol da emancipação da cultura judaica, chegando a ser um defensor declarado do sionismo no confronto com os judeus assimilados ${ }^{4}$ - portanto, em confronto com o próprio Kafka -, faz algo ainda mais grave: suprime o último parágrafo das anotações de 27 de dezembro, em que Kafka deixa clara sua posição de observação exterior, e não de participação, das pequenas literaturas: a tcheca (escrita no idioma tcheco) e a judaica (escrita em iídiche). Nesse enquadramento, Thirouin considera que o conceito de literatura menor está inteiramente apartado da obra que o teria inspirado, em razão de três procedimentos sucessivos: trata-se de um conceito formulado em absoluta desconsideração pela obra (procedimento realizado por Deleuze e Guattari), após ter sido traduzido equivocadamente (por Marthe Robert) de um texto manipulado (por Max Brod).

Seja porque considera a dimensão da luta política formulada no ensaio de Deleuze e Guattari demasiado abstrata, seja porque, ao contrário, localiza ali uma tentativa arbitrária e reducionista de compreender a obra

${ }^{4}$ Cf. Casanova, 2011, versão e-book, especialmente o capítulo "Prague: divisions politiques et déchirements intimes". 
kafkiana a partir de seu contexto político imediato, seja ainda porque o julga colaborador de uma ideia genérica de literatura, uma dimensão transcendental conceitualmente inapreensível, ou, finalmente, porque toma este ensaio como o resultado de uma reflexão autorreferida da cultura francesa, pouco interessada em compreender o que a produção exterior apresenta de singular e, ainda assim, bastante desenvolta para tratar de contextos linguísticos e culturais que mal conhece, a crítica recente da obra de Kafka desqualifica quase integralmente a interpretação apresentada pelos autores franceses, com base nos mais diversos fundamentos, alguns deles em franca oposição a outros. No entanto, há um significativo consenso quanto a um aspecto incontornável: a expressão pequena literatura cunhada por ele em seus diários não designava sua própria produção (escrita em alemão na condição de judeu assimilado), tal como propõem Deleuze e Guattari, mas duas outras: a literatura escrita em tcheco em Praga e aquela escrita em iídiche em Varsóvia.

Temos aqui um ponto de partida instigante: se a leitura cuidadosa dos diários de Kafka permite afirmar indubitavelmente que ele não falava de sua própria produção quando apresentava a noção de pequena literatura, por outro lado, não há impossibilidade a priori de que o analista da cultura possa reverter para a análise de uma determinada produção cultural o diagnóstico feito por seu autor acerca de outra produção que não a sua própria. Considerar esse procedimento uma impossibilidade implica invariavelmente investir a voz do autor de uma autoridade incontestável sobre sua própria obra, aceitando de forma naturalizada para a análise os limites que o autor colocou para a obra, o que é já um ponto de partida problemático para a análise da cultura. A meu ver, não se trata nem de um procedimento necessário nem impossível, merecendo ser examinado à luz do enquadramento metodológico da análise. Assim, não será esta a razão pela qual descartarei a leitura de Deleuze e Guattari.

A despeito dos inúmeros problemas apontados por uma crítica que, ainda na segunda década do século XXI, permanece retomando esse ensaio de 1975, há ali um insight que me parece ser ainda frutífero para a análise 
da relação entre literatura e política, para diversos contextos culturais, não só para a imbricada cena cultural de Praga. Qual seja, a percepção de que o problema da nacionalidade, apontado por Kafka em seu diário, possuía uma implicação territorial, fazendo entrecruzarem-se língua, nacionalidade e território na constituição do potencial político de uma forma de produção literária que fala em nome de uma coletividade.

O intuito deste artigo é o de explorar a mútua imbricação desses aspectos percebidos por Kafka e enfatizados, por vezes de maneira distorcida, por Deleuze e Guattari. Para isso, tomarei Kafka menos como um literato (não me importa aqui se a literatura kafkiana pode ou não ser lida por esse conceito) e mais como um analista da cultura de seu tempo - não necessariamente de sua própria obra - que localiza na literatura produzida sob determinadas circunstâncias um eixo político fundamental e um vetor de forte coesão social. Para isso, partirei da noção de pequena literatura explorando-a, em parte, a partir do tratamento dado a ela por Deleuze e Guattari (embora o faça descartando, naturalmente, a tradução equivocada do termo como literatura menor e seus desdobramentos analíticos), para examinar dois dos princípios em que apoiam sua análise dessas literaturas: a desterritorialização da língua promovida nessas circunstâncias e a necessária ligação da produção individual ao seu imediato-político (cf. Deleuze; Guattari, 2014, p. 39).

O objetivo aqui perseguido será o de testar a vitalidade dessa conjunção de princípios para delimitar o sentido político das literaturas produzidas em outros contextos igualmente pequenos. Dito de forma mais precisa: tratar-se-á de averiguar se o tripé em que Deleuze e Guattari sustentam a noção de pequena literatura formulada por Kafka pode ser aproximado das literaturas de outras duas pequenas nações para compreendê-las em suas singularidades e, com isso, aquilatar a força dessa noção como categoria analítica, não a partir de suas inconsistências em relação à proposição original de Kafka - questão sobejamente discutida pela crítica mais recente -, mas a partir da indução de elementos próprios de outras literaturas produzidas em circunstâncias assemelhadas. 
É nesses termos que buscarei desdobrar uma noção de pequena literatura a partir das obras de Fernando Pessoa e de Mário de Andrade, dois autores cujas nações são tomadas como um problema cultural e político a ser enfrentado em termos literários, autores que pensam a literatura como antecipação do amanhã - "A arte é um espelho, que adianta como um relógio, às vezes" (Kafka apud Janouch, 2012, p. 192) -, e, em certo sentido, consideram que ela seja "menos um assunto da história literária do que assunto do povo" (Kafka, 1997, p. 198).

A obra de Fernando Pessoa, múltipla tanto nos gêneros literários quanto na diversidade autoral envolvida no empreendimento da heteronímia, constitui-se como uma formulação moderna e singular de um ancestral espírito português, detentor de uma forte tradição cultural. De forma mais sistemática e programática do que Kafka, Pessoa produz uma análise crítica da cultura e da política portuguesas, introduzindo seu leitor, de diversas maneiras, em um tecido cultural em que sobrevivem o espírito e a vocação dessa nação de pioneiros descobridores, mas o faz em uma dicção inconfundivelmente modernista, diversa e fragmentada. Com isso, dá-nos acesso a uma dimensão coletiva da cultura portuguesa que tem seu acento político tão mais agudizado quanto mais distantes e irrecuperáveis se apresentam os atributos dessa nação.

A pertinência da seleção do trabalho crítico de Mário de Andrade fundamenta-se em sua multi-dimensionalidade, que faz convergirem análise da cultura, produção literária e musical e crítica política da nação em um único projeto modernizador, que se firma na mútua imbricação entre arte e política na cena cultural brasileira. Na obra desse autor, alicerça-se, assim, uma matriz cultural que excede a produção da literatura, lançando bases para uma forte tradição na crítica literária, na crítica cultural e no pensamento brasileiro, de expressões intelectuais que, inclusive, produziram uma bem estruturada grade conceitual que plasmaria o significado cultural desse movimento e o consagraria como o momento culminante do processo de desrecalque da cultura nacional, colocando-o, assim, como o corolário da emancipação em relação a um passado de colonização cultural. 
A seleção desses autores, contemporâneos entre si, justifica-se, 1) pela similaridade de suas preocupações, precisamente por uma combinação de fatores - em parte apontados por Deleuze e Guattari, em parte por Casanova - que Kafka articula na delimitação da noção de pequenas literaturas; 2) pela possibilidade de caracterizar os seus respectivos contextos sociais, embora distintos entre si, todos eles legíveis pela noção de pequenas nações formulada por Kafka; e 3) pelo interesse comum em oferecer soluções estéticas conectadas a um princípio fundador da nacionalidade, as quais, por isso mesmo, teriam que ser distintas entre si, já que se enraízam em contextos nacionais diversos.

Para manter a coerência com o estilo textual em que Kafka formula a noção de pequena literatura, tomarei os três autores também como produtores de textos literários, mas, fundamentalmente, serão tomados como analistas da cultura, de forma que é em seus textos analíticos que me apoiarei para avançar em meu argumento. Assim, optei por trabalhar, em Fernando Pessoa, com textos de análise da cultura portuguesa compilados no volume Sobre Portugal (1979) e com o manuscrito "A nova poesia portuguesa no seu aspecto psicológico" (1980); e, em Mário de Andrade, com as anotações feitas em suas incurções pelo Norte e Nordeste do país, compiladas no volume O Turista Aprendiz (1976), e com alguns dos textos que integram o livro Aspectos da Literatura Brasileira (2002). Em ambos os autores, as referências à sua literatura aparecerão apenas de forma subsidiária.

É importante ressaltar, desde já, que não se trata aqui, simplesmente, de aplicar às obras desses dois autores uma noção previamente dada, mas de buscar elaborar a partir delas um enriquecimento do conceito e, com isso, ampliar seu alcance analítico.

\section{O solo literário}

O ponto de estruturação da noção de pequena literatura, apontado por Deleuze e Guattari, sobre o qual me deterei, é o efeito de desterritorialização da língua em que ela é escrita, efeito que, na Praga do início do século XX, 
só se compreende quando se leva em conta a complexa situação idiomática para a qual chamam a atenção Scott Spector $(2000)^{5}$, Modesto Carone $(2009)^{6}$, Klaus Wagenbach $(2011)^{7}$ e Pascale Casanova $(2011)^{8}$. Carone sintetiza a questão nos seguintes termos:

Evidentemente todo esse traçado corre em paralelo à tensão entre as três culturas alemã, tcheca e judaica - que conviviam e colidiam umas com as outras em Praga. Transformada de periferia dos Habsburgo em capital do reino, ela foi até o fim do século XIX (Kafka é de 1883) uma cidade mais alemã do que tcheca, mas antes ainda da Primeira Guerra Mundial, que selou o fim da monarquia do Danúbio, Praga já era predominantemente tcheca, o que se consolidou de uma vez na República de Masarik (Carone, 2009, p. 54).

Tal multiplicidade cultural e idiomática, evidentemente, envolve uma multiplicidade de relações de poder que se rebatem no espaço literário e são exploradas por Casanova ao apresentar as diferentes posições dos grupos de literatos e seus conflitos político-linguísticos: o idioma tcheco, falado pela maioria da população, é suporte de produção do polo dominado do espaço literário, enquanto o alemão, língua culta e dominante, falado pela elite política e cultural, é o idioma dos "poetas oficiais do academismo germânico que se auto-designavam representantes patenteados da cultura alemã" (Casanova, 2011). O alemão é também o idioma em que escrevem os judeus assimilados, grupo que se subdivide em duas perspectivas irreconciliáveis: uma maioria afinada com a assimilação pela cultura alemã, adepta da separação entre arte e política, e uma minoria envolvida com o retorno às origens de uma nacionalidade judaica, minoria envolvida na retomada das origens da cultura popular que, para eles, deveria se exprimir em uma língua própria. Trata-se de um grupo de intelectuais judeus, dentre os quais

\footnotetext{
${ }^{5}$ Em especial o capítulo 3, intitulado "The territory of language".

${ }^{6} \mathrm{O}$ capítulo intitulado "Nas garras de Praga" trata mais detalhadamente desse tema.

7 Especialmente o capítulo intitulado "University, Society and Language in the Capital of Bohemia".

${ }^{8}$ Notadamente o capítulo "L'espace littéraire".
} 
figura Max Brod, que defende claramente o projeto sionista e é investido de força extraordinária a partir de 1909.

Casanova conecta essa problemática à herança filosófica de Johann Gottfried von Herder, cuja obra articula três noções fundamentais, as de nação, língua e povo, exercendo um forte impacto na cultura alemã que tematizou as relações entre essas três noções de forma sistemática ${ }^{9}$, notadamente nas discussões teóricas e estéticas do período de Kafka. A problematização dessas ligações, ao colocar a noção de Volk no centro de sua argumentação, "permitia ligar intrinsecamente as reivindicações nacionais e linguísticas" (Casanova, 2011). Casanova refere-se a esse universo de ideias como "pensamento folkista", o qual estabelece um "sistema" de pensamento sustentado em duas articulações principais: 1) a dependência necessária entre a nação e os habitantes que partilham do mesmo idioma, o que enseja a perspectiva de um nacionalismo linguístico; e 2) a dependência "entre os escritores e o 'povo', a quem cabia carregar, guiar, apoiar o que eles escreviam" (Casanova, 2011).

Dentro dessa concepção, o escritor que se enraíza em uma cultura e se intitula "popular" desempenha um papel fundamental que é o de ser o porta voz de um povo, do qual sua obra é emanação. Ele é aquele que vocaliza a verdade de um povo, que, por sua vez, o legitima e o justifica, em confronto direto com uma perspectiva da arte que a pretende autônoma, abstrata e intelectualista. Segundo Casanova, essa concepção atravessa, de alguma maneira, o conjunto dos movimentos nacionais da Europa central e do leste na segunda metade do século XIX.

A adoção desse folkocentrismo entre os escritores do Império que se identificavam com uma das causas 'nacionais' teve inúmeras consequências. Com efeito, não se tratava de um simples vocabulário ou de reivindicações de pertencimento a um

${ }^{9}$ Anne-Marie Thiesse enfatiza que é precisamente em defesa da autonomia da cultura alemã que o então jovem teólogo Herder começa a desenvolver uma perspectiva que correlaciona o idioma e a cultura na autonomia de um Povo: "Herder deixa uma obra de grande envergadura, investida de uma cultura enciclopédica e animada por uma constante preocupação: como fazer aceder a nação alemã, politicamente dispersa, à consciência de si mesma e lhe dar uma alta cultura." (Thiesse, 2001, p. 35-6). 
povo; o pensamento herderiano era, diz-se, uma lógica renovada da reflexão e da produção artística. Ele modificava as categorias a partir das quais a literatura havia sido até então avaliada e, consequentemente, dava lugar a uma verdadeira inversão de hierarquias, convicções e valores literários (Casanova, 2011).

Deleuze e Guattari apreendem a força política da literatura em outra dimensão do tecido social. Partindo das reflexões de Kafka na célebre passagem de dezembro de 2011 de seus Diários, jogam luz sobre as relações de poder envolvidas no uso dos diversos idiomas e na possibilidade de convertê-los em arma política a partir de seu enraizamento territorial. O fenômeno que denominam desterritorialização é aquele percebido por Kafka quando observa a importância para os judeus de Varsóvia e para os tchecos de Praga de escrever em suas línguas nativas num espaço dominado pela cultura alemã. Essa observação de Kafka aponta um descompasso territorial entre uma população majoritariamente tcheca e uma cidade em que o alemão é a língua oficial. Esse apontamento de Kafka é desdobrado por Deleuze e Guattari em dois movimentos concomitantes: uma desterritorialização dos autores em relação à sua territorialidade tcheca - já que se veem obrigados a escrever em uma língua que não a sua própria, ainda que este seja o povo originário daquele território - e uma desterritorialização da língua alemã, que, não sendo originária do povo que vive naquele território, transforma-se em uma

língua cortada das massas, como uma 'linguagem de papel' ou de artifício; com mais forte razão os judeus que a um só tempo, fazem parte dessa minoria e são delas excluídos, tais como 'ciganos tendo roubado a criança alemã no berço' (Deleuze; Guattari, 2014, p. 36).

A desterritorialização de que falam Deleuze e Guattari envolve, assim, uma dupla migração idiomática que, manejada dessa forma, permite-nos convertê-la no questionamento da autenticidade de uma determinada produção cultural, medida a partir de seu enraizamento territorial. Ainda que Kafka não tenha mencionado especificamente o termo territorialidade ou território em sua apreciação das pequenas literaturas, o autor menciona 
o espaço dessa produção, que, neste caso, é caracteristicamente exíguo. Pensá-lo em termos de território é o aporte trazido por Deleuze e Guattari à análise, adensando conceitualmente uma perspectiva lançada de forma pouco pretensiosa numa nota de diário.

De que maneira a literatura de Kafka tem lugar nessa reflexão sobre as pequenas literaturas? Ainda que essa expressão não tenha sido usada por Kafka para designar sua própria obra, como argumenta Corngold de maneira bastante convincente em uma leitura minuciosa dessa passagem dos Diários, mesmo este autor aponta um aspecto importante da forma como Kafka usa o alemão em sua obra, também reconhecido por Modesto Carone e por Deleuze e Guattari:

É a universalidade concreta da imagem dialética que se pode encontrar na sua cor local? Acho que não. O que é verdadeiramente dialético em Kafka, como Benjamin sugere, é a destruição das metáforas e da imagem dada. As imagens de Kafka não são propriamente imagens - elas não são positivas. Antes, elas são negativas: elas são produtos cindidos da destruição (metamotfose, desconstrução) das imagens de metáforas padrão (Corngold, 2004, p. 288, grifo do autor).

Esse aspecto do alemão de Kafka é percebido por Carone no sentido de afastar qualquer possibilidade de imputar à literatura de Kafka um dialeto local que resultasse de um alemão entremeado pelo tcheco e pelo iídiche, tal como afirmam Deleuze e Guattari, mas é no uso de um alemão sóbrio e ressecado (sem figuras de linguagem, sem imagens etc.) que reside exatamente a força política dessa literatura:

À diferença destes [seus companheiros de geração], que buscavam superar o becosem-saída do alemão cartorial da classe dirigente por meio de uma inventividade verbal postiça, o autor da Carta ao pai foi pelo caminho inverso, assumindo a linguagem desvitalizada da burocracia como instrumento inesperado de criação literária. Klaus Wagenbach descreveu o idioma germânico praticado em Praga como uma língua de cerimônia subvencionada pelo Estado - e foi dele que saiu, como pão do forno, o famoso protocolo kafkiano. Pois era justamente aquele tipo de esclerose linguística que vinha facilitar o exame à distância de cada palavra (coisa que talvez um dialeto não permitisse), circunstância que transparece no recuo narrativo, no rigor vocabular 
e na sintaxe empertigada de Kafka, principalmente a partir de O veredicto (1912), ponto de inflexão de sua obra (Carone, 2009).

Ora, é esse aspecto que investe o alemão manejado por Kafka de força política. Se Deleuze e Guattari atribuem equivocadamente um caráter reflexivo à expressão kafkiana de pequena literatura, isso não invalida um outro aspecto ressaltado por eles que é o da localização do teor político da obra de Kafka no uso ressecado da língua, capaz, como o artista da fome, de fazer da sua míngua a sua arte:

Já que o vocabulário é ressecado, [é necessário] fazê-lo vibrar em intensidade. Opor um uso puramente intensivo da língua a todo uso simbólico [...]. Chegar a uma expressão perfeita e não formada (Deleuze; Guattari, 2014, p. 40).

Esse aspecto é ressaltado por Klaus Wagenbach, que, citando Fritz Mauthner, estabelece uma correlação entre a fisionomia da literatura de Kafka e a pobreza do alemão falado no interior da Boêmia pela comunidade rural tcheca:

O purismo característico de Kafka, a construção sóbria de suas sentenças e seu vocabulário esparso são impensáveis fora do contexto do alemão de Praga. Sua decisão de se restringir aos recursos linguísticos limitados do seu contexto é simplesmente honestidade - embora a absoluta extravagância do estilo Kunstwart possa ter sido um fator que contribuiu. O sentido de Kafka da 'estranheza' das coisas também pode ser conectado a seu contexto linguístico. Havia sempre algo proibido e estranho no seco e protocolar estilo do alemão de Praga, bem ali, no uso das palavras individuais (Wagenbach, 2011).

Esse permanente contato linguístico do alemão de Praga com o tcheco e o iídiche talvez enseje parte da grande dose de invenção empreendida por Kafka.

Sob títulos diferentes, Kafka nunca deixou de definir a si mesmo como alguém que pertencia a esse triângulo das Bermudas centro-europeu: à minoria alemã pela cultura e pela língua em que escrevia, à população tcheca cujas aspirações legítimas apoiava, e aos judeus com quem mantinha laços de origem (Carone, 2009). 
Ainda que o alemão de Kafka não seja o distinctive language of a people, tal como Corngold afirma enfática e repetidas vezes, o uso preciso que Kafka faz do alemão, sua língua primeira, quer tenha sido motivado politicamente, quer não, possui um efeito político quando pensado à luz do contexto em que Kafka se formou como literato, pois é justamente na reflexão sobre a necessidade de escrever em um idioma duplamente desterrado e pelas relações de poder que atravessam esse desterro, que Kafka formula a noção de pequena literatura. Com isso, o autor evidencia e aprofunda a tensão colocada pelo duplo processo de desterritorialização apontado por Deleuze e Guattari: pela artificialidade do alemão falado em Praga e pelo papel restritivo que aí é reservado ao tcheco e ao iídiche. Duplo processo de desterritorialização, que Kafka permite entrever em termos de pertencimento, de enraizamento, e, portanto, de autenticidade.

$$
* * *
$$

A relação entre idioma e território que Deleuze e Guattari formulam, a partir de Kafka, em termos de desterritorialização, é também crucial na literatura de Fernando Pessoa, sobretudo para que se possa aquilatar de forma apropriada a importância que tem Portugal como tema na obra pessoana. Aqui é necessário aproximarmo-nos da relação de Pessoa com o território português, a partir de uma breve nota biográfica: após o falecimento do pai e do novo casamento da mãe com o comandante João Miguel Rosa, Pessoa se muda com a família, aos 5 anos de idade, de Lisboa para Durban, na África do Sul, onde seu padrasto ocupa o cargo de cônsul de Portugal (Bréchon, 1998, p.34). Educado e cultivado em um ambiente cultural anglosaxão, Pessoa retorna definitivamente a Portugal em 1905, aos 17 anos de idade. Esse retorno constitui para o poeta um encontro aterrador com um território, um tempo e uma língua, que se entrecruzam constituindo um amálgama nunca inteiramente recuperado:

Pessoa, ao poisar os pés em terras portuguesas (1905), sentiu fugir-lhe a pátria que um dia, lá longe, imaginara. Encontrou-a moribunda e humilhada. Uma pátria 
estilhaçada que vivia de costas voltadas para o presente na sua cega subserviência ao que vinha do estrangeiro, muito particularmente, de Inglaterra. E sentiu como sua a desesperança dessa pátria sofrida (Medeiros, 2008, p. 667).

O retorno a Portugal como regresso de alguém que adota a antiga casa como nova e jamais encontrará ali a naturalidade de quem nunca houvesse partido é uma temática incontornável de sua literatura. Anos depois, em 1923 e 1926, Pessoa, sob o heterônimo Álvaro de Campos, escreve dois poemas em que narra esse reencontro, ambos com o mesmo título em inglês - Lisbon revisited:

\section{Lisbon revisited (1926)}

(...)

Outra vez te revejo,

Cidade da minha infância pavorosamente perdida...

Cidade triste e alegre, outra vez sonho aqui...

(...)

Outra vez te revejo,

Com o coração mais longínquo, a alma menos minha.

Outra vez te revejo - Lisboa e Tejo e tudo -,

Transeunte inútil de ti e de mim,

Estrangeiro aqui como em toda parte,

Casual na vida como na alma,

Fantasma a errar em salas de recordações,

Ao ruído dos ratos e das tábuas que rangem

No castelo maldito de ter que viver...

(...)

Outra vez te revejo,

Mas, ai, a mim não me revejo!

Partiu-se o espelho mágico em que me revia idêntico,

E em cada fragmento fatídico vejo só um bocado de mim -

Um bocado de ti e de mim!... (Campos, 1997, p. 225).

O tempo da história pessoal do poeta, recuperado em um laborioso processo de rememoração, entrecruza-se com o tempo na nação portuguesa, outro tema incansavelmente perseguido por Pessoa. Para 
melhor compreender essa conexão, tratemos de contextualizar o retorno de Pessoa em uma certa atmosfera cultural.

O Portugal reencontrado por Pessoa é tudo menos ordinário. O país vive, naquele momento, um processo de convulsão política que foi desencadeado, 15 anos antes, pela disputa com a Inglaterra do território africano que liga Angola a Moçambique (cf. Teixeira, 1990). Após o que se convencionou chamar de Ultimatum inglês - imposição da Inglaterra, em janeiro de 1890, da retirada de Portugal daquele território -, a crise política não cessa de se aprofundar, deixando claro que Portugal encontrava esgotadas as condições de manter o império que conquistou pelo pioneirismo das aventuras marítimas. Essa crise de política externa se converte em uma convulsão interna em que se mesclam discursos de indignação e de sentimento de humilhação, pondo em questão, ao longo do processo, o próprio regime monárquico. Em 1908, o rei D. Carlos e seu primeiro herdeiro na linha sucessória, D. Luís Felipe, são assassinados no Terreiro do Paço, em Lisboa, e, dois anos mais tarde, não é mais possível deter a instauração da República (Medina, 1990; Catroga, 2010; Reis et al., 2010).

A crise política e sua subsequente transformação inseminarão o mundo da cultura de maneira bastante transversal. Portugal, que mesmo para os movimentos literário precedentes ocupou lugar de destaque, aparece provavelmente como o grande tema da literatura daqueles anos, trazendo alguns de seus atores para dentro da cena política. O imediato político e o fazer literário entrelaçam-se de maneira bastante contundente, de maneira que sequer parece possível pensar em uma esfera autonomizada da arte naquele contexto. Há mesmo casos de literatos que ocupam papéis políticos de destaque, como é o caso de Teófilo Braga, que se transforma no primeiro presidente do Governo Provisório da República portuguesa, e de Guerra Junqueiro, nomeado embaixador na Suíça no governo republicano.

A crise final da Monarquia, a revolução republicana e o regime dela saído, os anos da Grande Guerra, o consulado de Sidónio Pais e o período subsequente ao seu assassinato, a agonia da Primeira República, a Ditadura Militar (1926-1933) e os 
começos do Estado Novo de Salazar foram as sucessivas situações políticas sobre que se debruçaram esses escritos políticos pessoanos (Barreto, 2015, p. 191).

Mas, desde logo, diferentemente de Guerra Junqueiro ou Teófilo Braga, Pessoa nunca pretendeu imbricar de maneira direta literatura e política, tendo mantido, o mais das vezes, uma distância temática e estética entre seus escritos literários e suas reflexões políticas, estas últimas marcadas, inclusive, por pretensões científicas. No entanto, Portugal interessa-lhe em uma dimensão entrecruzada com sua experiência pessoal, de forma que o contexto de origem, a primeira infância e a língua portuguesa parecem faces combinadas que, no reencontro, assombram o então jovem poeta.

O Portugal que emerge da literatura pessoana, notadamente em Mensagem, é um Portugal sonhado e irrecuperável, inseminado pela história, mas distanciado dela. Trata-se de uma pátria sonhada, que só pela literatura se poderia alcançar:

Embora não tenha ainda, em 1912, clara visão do 'Quinto Império', que há de vir, já sabe que sua força não virá das armas nem das leis, mas do que se faz 'daquilo de que os sonhos são feitos'. Os futuros conquistadores portugueses serão poetas. Seu chefe será o grande poeta anunciado, rival de Homero e de Shakespeare (Bréchon, 1998, p. 156-7).

Em texto publicado n'A Águia, em setembro de 1912, Pessoa sedimenta essa ideia, explicitando o traçado que haveria de ter o Quinto Império:

E a nossa Raça partirá em busca de uma Índia nova, que não existe no espaço, em naus que são construídas 'daquilo de que os sonhos são feitos'. E o seu verdadeiro e supremo destino, de que a obra dos navegadores foi o obscuro e carnal antearremedo, realizar-se-á divinamente (Pessoa [1912] 1998, p. 397).

A dimensão mítica e messiânica da escrita pessoana adquire, nesses dois trechos, toda a sua amplitude e mostra-se inseparável da temática da nação portuguesa, que permanece instigando novos olhares sobre o conjunto de sua obra. Uma série significativa de textos políticos encontrados no espólio 
do autor, depositado na Biblioteca Nacional de Portugal, foram coligidos por Maria Isabel Rocheta e Paula Mourão, no volume intitulado Sobre Portugal: Introdução ao problema nacional, em 1979, trazendo a público a centralidade da preocupação de Pessoa com o tema da nação portuguesa. Em 2011, uma nova publicação, organizada por Pedro Sepúlveda e Jorge Uribe (2012), reorganiza esses textos e a eles acrescenta inúmeros textos inéditos que, do ponto de vista dos organizadores, permitem acompanhar o amadurecimento da relação entre o Sebastianismo e o Quinto Império, em Pessoa. É justamente nessa mútua imbricação que se pode entrever a tonalidade messiânica da escrita política de Pessoa, de forma a situar em um império por vir a redenção de um Portugal que, enfim, impor-se-ia como um império de cultura.

$\mathrm{O}$ aspecto, a meu ver, mais interessante da forma como Uribe e Sepúlveda veem essa temática em Pessoa é uma espécie de reorientação da crítica clássica, que buscou minuciosamente compreender a heterogeneidade da criação pessoana, dispersa não só por temas e gêneros literários diversos, mas em uma multiplicidade de autorias. O fenômeno da heteronímia recebeu inúmeras formulações teóricas ao longo dos seus pouco mais de cem anos ${ }^{10}$, o que foi fundamental para que pudesse ser compreendida em toda a sua envergadura. Em uma visada inovadora, o que os críticos propõem em apresentação a essa nova organização dos textos políticos de Pessoa, intitulada Sebastianismo e Quinto Império, é uma correlação que não visa subtrair da criação pessoana a sua diversidade, mas pensa de forma aproximada a criação heteronímica, e, portanto, lírica, e a preocupação com um Portugal mítico que se reconstituiria como império de cultura. Na esteira de José Augusto Seabra, para quem as expressões "nacionalista místico" e "sebastianista racional" com que Pessoa se define envolvem

$\overline{10}$ O dia 08 de março de 1914 foi denominado por Pessoa "dia triunfal". É a data em que o autor fixa como aquele do surgimento da heteronímia, muito embora desde a infância ele tenha se entretido com a criação de textos cuja autoria atribuía a nomes por ele inventados. 
"uma acepção que, pela sua própria contradição nos termos - pela sua coincidentia oppositorum -, transcende qualquer significação referencial, política ou histórica" (Seabra, 1988, p. 96), Uribe e Sepúlveda afirmam que

Centrando o seu pensamento sobre a nacionalidade no domínio do mito, Pessoa é plenamente consciente do seu cunho ficcional e que transcende uma factualidade histórica e sociopolítica (Uribe; Sepúlveda, 2012, p. 158).

Portugal aparece na obra de Pessoa com igual pujança, seja nos textos em que aparece a dimensão pessoal do poeta, seja daqueles que tematizam a nação. Ambas as dimensões são atravessadas pela temática da pátria portuguesa, de forma que tanto a Lisboa pavorosamente perdida na infância do poeta quanto a grande nação que espera pelo retorno do messias são um espaço ficcional em Pessoa.

Nesse cenário, a língua portuguesa adquire importância fundamental como espaço de enraizamento do poeta, eternizado na célebre frase "minha pátria é a língua portuguesa". Trata-se, na verdade, de um reenraizamento que só pôde se dar na língua portuguesa. A descrição feita por Pessoa da descoberta de Padre António Vieira talvez seja o trecho mais emblemático, em toda sua obra, do lugar fundante que a língua portuguesa tem para si:

Não choro por nada que a vida traga ou leve. Há porém páginas de prosa que me têm feito chorar. Lembro-me que, como do que estou vendo, da noite em que, ainda criança, li pela primeira vez numa selecta, o passo célebre de Vieira sobre o Rei Salomão. "Fabricou Salomão um palácio..." E fui lendo, até ao fim, trémulo, confuso; depois rompi em lágrimas felizes, como nenhuma felicidade real me fará chorar, como nenhuma tristeza da vida me fará imitar. Aquele movimento hierático da nossa clara língua majestosa, aquele exprimir das ideias nas palavras inevitáveis, correr de água porque há declive, aquele assombro vocálico em que os sons são cores ideais - tudo isso me toldou de instinto como uma grande emoção política. E, disse, chorei; hoje, relembrando, ainda choro. Não é - não - a saudade da infância, de que não tenho saudades: é a saudade da emoção daquele momento, a mágoa de não poder já ler pela primeira vez aquela grande certeza sinfônica. Não tenho sentimento nenhum político ou social. Tenho, porém, num sentido, um alto sentimento patriótico. Minha pátria é a língua portuguesa. Nada me pesaria que invadissem ou tomassem Portugal, desde que não me incomodassem pessoalmente. Mas odeio, com ódio verdadeiro, com o único ódio que sinto, não quem escreve mal português, não 
quem não sabe sintaxe, não quem escreve em ortografia simplificada, mas a página mal escrita, como pessoa própria, a sintaxe errada, como gente em que se bata, a ortografia sem ípsilon, como o escarro directo que me enoja independentemente de quem o cuspisse (Pessoa como Bernardo Soares, [1931] 1996, p. 280-1).

Isso não significa, por outro lado, desconectar a literatura de seu imediato político. De forma diversa, Pessoa encontra uma forma particular de posicionar uma dimensão em face da outra, de maneira a assegurar que a literatura não se dissolva em exigências que não são as suas. No entanto, internamente à literatura, Portugal assume toda a sua dimensão política, constituindo-se como o núcleo de consagração de uma língua e de uma cultura, lugar onde se antecipa a chegada do Quinto Império e, o que é mais importante, lugar em que ele há de se constituir.

A defesa da autonomia da arte é imprescindível para Pessoa, por duas razões diversas: em primeiro lugar, para alinhar a sua obra com uma tônica geral do modernismo, segundo a qual a arte deve se ocupar de suas próprias questões e não se mover impulsionada por reivindicações de outra ordem; em segundo lugar, e de forma mais importante para o meu argumento, porque a impossibilidade de se formular, nas condições históricas em que Portugal se encontrava, uma saída de ordem política cria as condições para que Pessoa conceba literariamente um outro Portugal, aquele que só pode existir num lugar literário.

Em texto coligido no volume Sobre Portugal, Pessoa elabora sua definição de $V$ Império, ligado a um projeto de criação de um imperialismo de cultura liderado pelo povo português, o que encontraria fundamento na perspectiva que toma as Descobertas como um ato de cultura e define Portugal como o descobridor da ideia mesma de descoberta, e, nesse sentido, fundador do mundo moderno. O fundamental aqui é entender que, em se tratando de um imperialismo cultural, a literatura é quem exerce o papel central, já que a ideia de nação, para Fernando Pessoa, é equivalente da língua. Trata-se, no limite, de um projeto de elaboração literária do mundo político (cf. Pessoa, 1979, p. 223). Como o Portugal almejado pelo trabalho crítico de Pessoa possui uma vocação imperialista, 
em completo desacordo com as condições históricas de seu momento, era necessário formulá-lo literariamente, concebê-lo como matéria de que os sonhos são feitos.

A comoção de Pessoa com a língua portuguesa é substantivamente marcada por aquele reencontro de 1905. Não se trata de uma relação natural e sem distanciamento, mas de uma paixão desencadeada pelo assombro do reencontro. Seduzido por essa entidade que é o seu país e a sua língua materna, ele atualiza a tradição sebastianista, sublinhando a vocação imperial de Portugal. O movimento proposto por ele é de um mergulho da cultura portuguesa em seu próprio passado e na sua própria tradição. Se o poeta, de volta de seus anos de formação na África do Sul, experimenta uma espécie de reterritorialização na pátria-língua portuguesa, o império de cultura que ele formularia anos mais tarde requereria um processo similar: um voltar-se a si mesmo e à sua tradição, ainda que em roupagens renovadas. Assim como ele próprio, a cultura portuguesa havia de ser reterritorializada nesse Portugal sonhado por Pessoa, tão moderno, ainda que imerso na tradição sebastianista.

Processo ainda diverso, mas em certa medida aparentado, é o que promove Mário de Andrade entre o idioma brasileiro e o território nacional. É tarefa desnecessária buscar apresentar ao leitor brasileiro a relevância da figura de Mário de Andrade para o modernismo brasileiro, em especial o paulista. Esse é seguramente o autor do modernismo paulista mais comprometido com uma proposta programática de mergulho nos conteúdos nacionais para se alcançar uma transformação verdadeiramente moderna da arte brasileira. É em sua obra que se encontram as páginas mais entusiasmadas de valorização da cultura popular como lugar de onde se retirar elementos autenticamente nacionais para construção de uma nova linguagem que elevasse à norma culta (cf. Souza, 2003, p.29) toda a riqueza que percebia no manejo da língua vernacular. Esse tema ocupa tamanha centralidade em sua obra, que é possível dizer, sem grande risco 
de errar, que toda a sua fortuna crítica teve de se haver com ele, de uma forma ou de outra.

Meu interesse aqui é bastante pontual: buscarei aquilatar a importância do território nacional e de sua conexão com o idioma brasileiro no projeto cultural de Mário. Daí a importância de seus registros de viagem na construção não só de textos de ficção, como Macunaíma (publicado no ano seguinte à sua viagem à Amazônia), mas em seu trabalho de crítica da cultura.

Da crítica clássica à mais contemporânea que vem se dedicando ao tema da viagem em Mário, parece haver um consenso sobre a importância decisiva das poucas vezes em que o autor deixou São Paulo para a riqueza de elementos folclóricos e populares de que sua obra foi investida. Há um dissenso, no entanto, acerca do estatuto de etnografia de seus relatos de viagem. José Tavares Correia de Lira é bastante atento ao movimento de mão dupla que caracteriza a atenção de Mário aos aspectos "primitivos" dos inúmeros cenários que atravessou em viagem ao Nordeste. Esse interesse quase obsessivo pelo "outro" está claramente motivado, segundo Lira, por uma busca do conhecimento de si:

Talvez porque a sua viagem se situasse entre a missão cultural, a campanha etnográfica, a visita aos amigos distantes e às terras inspiradoras, Mário tenha sido capaz não apenas de abarcar aquilo que bem depois se tornaria mercadoria turística (...) mas também de lograr, em sua fruição, transcendê-lo na predisposição à aventura e à empatia com o outro, na prática do 'despaisamento'. O que isso significava para ele? (...) Significava também compreender como viviam aqueles lá, sobretudo os que pareciam tão distantes de seu ponto de partida: sitiantes, camponeses, proletários, migrantes - observar como falavam, a maneira de contar e de sorrir, de cantar e de dançar, de andar e trabalhar, de morar e cultuar. Despaisar-se era poder sentir-se em casa no outro (Lira, 2005, p. 158-9, grifos meus).

O "sentir-se em casa no outro", nesse caso, parece-me poder ser mais concretamente situado na dimensão política do projeto cultural de Mário. Isso porque todo o trabalho de apanhar a diversidade cultural brasileira faz-se a serviço do que se convencionou chamar de desrecalque 
da cultura nacional, e o conhecimento atinado do outro envolve, nesse caso, o trabalho minucioso de construção consistente de um "nós", cujas singularidades diferenciam-nos de um outro ainda mais distante que é o colonizador e seus padrões culturais. O encantamento de Mário pelas relações, os rituais, a arquitetura, a música, o folclore, a miudeza do dia a dia que o absorvem em suas viagens, nesse sentido, não resultam de um interesse por um outro qualquer, mas por um outro histórica e culturalmente amarrado a si, um outro que, consigo, constitui um conjunto, verdade internamente heterogênea que é a cultura brasileira. O que Mário estabelece aí é uma aliança política.

Nesse sentido, a dimensão etnográfica dos relatos de viagem de Mário nubla-se num sentido ainda diverso daquele já apontado por André Botelho ao tratar especificamente da viagem à Amazônia. Botelho salienta a importância das reminiscências de leitura que Mário leva na bagagem, modulações literárias daquele lugar simbólico que, para ele, são mais importantes do que o desvendamento do que lá encontra:

Derivada da contraposição entre o que chama de "consciência lógica" e "consciência poética", trabalhada noutros textos, Mário afirma que, para ele, as "reminiscências de leitura me impulsionaram mais que a verdade" (Botelho, 2013, p. 37).

Botelho chama a atenção aqui para a precedência do elemento ficcional presente nas reminiscências de leitura em relação ao registro do que lá se encontrou. Essa motivação de descobrimento, que teve, em princípio, o estímulo adicional de ser uma reedição da caravana por Minas, projeto que se frustrou com a desistência de parte importante dos viajantes, é, assim, uma motivação interessada, toda fantasiada antes mesmo da partida. Tal precedência compromete o caráter etnográfico da incursão de Mário pela Amazônia. Seguindo essa pista, é interessante perceber, ainda, que o aspecto ficcional ganha relevância não só como formação de um conjunto de impressões que antecedem a viagem como, quando do retorno, também, e talvez sobretudo, sua obra ficcional se privilegia de suas impressões de viagem. Vale lembrar que Macunaíma é publicado no ano seguinte à viagem, 
mas, como aponta Botelho, pela menos uma versão já estava pronta antes da partida. A esse respeito, diz Mário em prefácio ao livro:

Evidentemente não tenho pretensão de que meu livro sirva pra estudo científico de folclore. Fantasiei quando queria e sobretudo quando carecia para que a invenção permanecesse arte e não documentação seca de estudo. [...] Os meus livros podem ser resultado dos meus estudos porém ninguém não estude nos meus trabalhos de ficção, leva fubeca (Andrade, [1928] 2008, p. 158).

Mesmo que se tenha em conta as diferenças entre a viagem à Amazônia e a viagem ao Nordeste, esta última intitulada "viagem etnográfica" pelo próprio autor, a conexão entre elas no que se refere ao enriquecimento substantivo do programa político-cultural de Mário, ficcional ou não, é inegável, assim como o é a centralidade do projeto de consolidação cultural da nação. A incursão pelo território nacional resulta na coleção de impressões que justamente dão forma e substância a esse projeto, ainda que grande parte dessas notas de viagem não lhe tenha servido de matéria-prima para obras futuras e tenham sido publicadas na forma mesma de diário.

Para o modernista Mário de Andrade, empenhado em entender a realidade brasileira dentro de um quadro latino-americano e em traçar, na medida de suas possibilidades, as coordenadas de uma cultura nacional, tomando o folclore e a cultura popular como instrumentação para seu conhecimento do povo brasileiro, foi muito importante unir a pesquisa de gabinete e a vivência de vanguardista metropolitano ao encontro direto com o primitivo, o rústico e o arcaico, que, em seu enfoque dialeticamente dinâmico, puderam lhe valer como indícios de autenticidade cultural (Lopez, 1976, p. 15).

Talvez pareça contraditório tomar esses registros de viagem como uma incursão territorial quando se tem em conta que, no prefácio a Macunaíma, Mário anuncia sua pretensão "desgeografizante" do Brasil, pretensão cujo sentido era dissolver ou subverter as localizações e distâncias. Eis as suas considerações:

Me parece que os melhores elementos duma cultura nacional aparecem nele. Possui psicologia própria e maneira de expressão própria. Possui uma filosofia aplicada entre otimismo ao excesso e pessimismo ao excesso dum país bem onde o praceano 
considera a Providência como sendo brasileira e o homem da terra pita o conceito da pachorra mais que fumo. Possui aceitação sem timidez nem vanglória da entidade nacional e a concebe tão permanente e unida que o país aparece desgeograficado no clima na flora na fauna no homem, na lenda, na tradição histórica até quando isso possa divertir ou concluir um dado sem repugnar pelo absurdo (Andrade, [1928] 2008, p. 159).

O sentido de territorializar não é avesso à tese de desgeografização defendida aqui. Diversamente, ele se refere à ideia de pertencimento, enraizamento e autenticidade como tensionamento da relação de poder entre grupos que se definem em termos linguísticos. Falamos, evidentemente, da relação com o português de Portugal. De forma que se essas regiões ou diferenças estão próximas ou distantes, nada se altera em termos de seu pertencimento e da sua autenticidade, que teriam produzido inclusive o intento de uma gramática própria. A questão, portanto, não é geopolítica mas cultural.

A unidade nacional, que julga permanente e é dada pela cultura popular, é o que justifica o desalojamento da herança cultural do colonizador. É uma unidade que abriga uma diferença e uma singularidade.

Como se sabe, é no âmbito de um amplo projeto, que Mário aparece como um dos maiores entusiastas da incorporação do vernáculo na construção de uma nova língua culta, mais autêntica. Essa língua se descola de uma erudição de importação, tomada como língua artificial e como sintagma de um espírito colonizado, para se enraizar na cultura nacional, diretamente ligada ao seu território de pertencimento. Não se trata, evidentemente, de um território físico, mas da reivindicação da autonomia de uma cultura e, dentro dela, de uma língua, em um determinado lugar. Território aqui é pensado como lugar de pertencimento.

A língua, então, para a qual se pensa inclusive uma gramática própria, passa a ser necessariamente remetida ao seu território, e, nesse sentido, engendra um processo que chamarei de hiperterritorialização como passo necessário para a descolonização do espírito nacional. Não se pode desconsiderar a semelhança entre duas viagens importantes para 
a obra marioandradiana: a viagem do autor à Amazônia, em 1927, e, no ano seguinte, a viagem do herói que parte da Amazônia em direção a São Paulo, desenhando, num longo percurso pelo território nacional, a narrativa que subverte geografias e ritos e é conduzida por um narrador que segue "cantando na fala impura as frases e os casos de Macunaíma, herói de nossa gente." (Andrade, [1928] 1979, p. 222, grifos meus).

Em uma visada bastante pessoal e um tanto melancólica, apresentada quase 20 anos depois da Semana de Arte Moderna, Mário reflete sobre o sentido do modernismo e sua contribuição para a cultura nacional, colocando a força do movimento na possibilidade de fusionar três princípios que já haviam aparecido em outros momentos da história cultural brasileira, mas nunca de forma simultânea e combinada. São eles:

o direito permanente à pesquisa estética [para ele a grande conquista do movimento modernista]; a atualização da inteligência artística brasileira; e a estabilização de uma consciência criadora nacional (Andrade, [1940] 2002, p. 266).

O primeiro item assegura a superação de uma característica que teria marcado todas as manifestações artísticas precedentes, à exceção do Romantismo: o endosso permanente do academicismo. Na medida em que "os artistas brasileiros jogaram sempre colonialmente no certo" (Andrade, [1940] 2002, p. 266), via-se inviabilizada de antemão a possibilidade de uma pesquisa estética que buscasse capturar a atualidade e a autenticidade brasileiras.

Como principal conquista do movimento modernista, foi instaurado um projeto de escavação de materiais brasileiros que permitiam cravar a fatura artística no que o autor denomina entidade coletiva nacional. Um trabalho artístico "não apenas acomodado à terra, mas gostosamente radicado em sua realidade" (Andrade, [1940] 2002, p. 267). O inconformismo e a contestação que eram necessários a uma arte que se pretendia revolucionária, como a arte moderna, só poderiam brotar de uma "verdadeira consciência da terra" (Andrade, [1940] 2002, p. 267, grifos meus). 
Daí seu incansável esforço para incorporar à lingua escrita a linguagem vernacular. A possibilidade dessa incorporação resulta da normalização do espírito de pesquisa estética, que assegurou a estabilidade de uma inteligência nacional e pôde ser tomada como prova da sua independência.

Ora, se o autor considera que os movimentos espirituais precedem as transformações sociais de outra ordem, é preciso ter em conta também que, muito cedo, Mário manifestou a necessidade de que esse projeto se expandisse para além da dimensão estética. Com o vigor adquirido nesse mergulho na entidade coletiva nacional, essa literatura é investida de pretensões extra-literárias: não se tratava apenas de transformar as linguagens no mesmo espírito revolucionário das vanguardas europeias, mas de incorporar no plano da cultura um projeto de modernização do país, estruturado no trabalho de colheita no terreno cultural nacional dos seus materiais mais característicos, dar-lhe uma forma inovadora e liberar a arte e o pensamento nacionais da necessidade de se submeterem a modelos de importação. Tratava-se, assim, de descolonizar a inteligência nacional:

Ele [o Modernismo] não era uma estética, nem na Europa nem aqui. Era um estado de espírito revoltado e revolucionário que, si (sic) a nós nos atualizou, sistematizando como constância da Inteligência nacional o direito antiacadêmico da pesquisa estética e preparou o estado revolucionário das outras manifestações sociais do país, também fez isto mesmo no resto do mundo, profetizando estas guerras de que uma civilização nova nascerá (Andrade, [1940] 2002, p. 275).

Na concepção de Mário, a arte excede sua dimensão propriamente estética e "tem uma funcionalidade imediata social, é uma profissão e uma força interessada na vida." (Andrade, [1940] 2002, p. 276). A arte, assim, transforma-se em um amálgama complexo de forças vitais socialmente produzidas que se manifestam em expressões esteticamente investidas. Eis a articulação que resulta da tomada da arte como "força interessada da vida". Não existe, aqui, nenhuma forma de valorização da arte pela arte. Ao contrário, encontra-se aqui uma concepção da arte profundamente conectada com o seu contexto social. 
Ora, o componente político de uma tal concepção da arte quase fala por si mesmo, sobretudo quando se toma essa afirmação à luz do projeto de descolonização cultural como era o de Mário de Andrade. Em um poema de Losango Cáqui, livro de 1924, o próprio autor apresenta esse projeto na forma de luta e a si mesmo como combatente:

Mário de Andrade, intransigente pacifista, internacionalista amador, comunica aos camaradas que bem contra-vontade, apesar da simpatia dele por todos os homens da Terra, dos seus ideais de confraternização universal, é atualmente soldado da República, defensor interino do Brasil (Andrade, [1924] 1979, p. 82).

Dessa forma, o que Mário nos apresenta é projeto de enraizamento da cultura brasileira no território nacional. Toda a argumentação é permeada pela reivindicação da autenticidade de determinadas expressões que pertencem a esse terreno e pelo descarte daquilo que, não tendo brotado do terreno nacional, foi trazido de fora. O critério de autenticidade é atravessado pelo pertencimento a uma cultura que se realiza num certo território.

No trabalho crítico de Mário de Andrade, aparece, portanto, um movimento correlato daquele que Deleuze e Guattari encontram nas reflexões de Kafka: uma dupla migração idiomática está em jogo. Trata-se de desterritorializar o português europeu, descartando-o dos usos locais, e fincar a bandeira do português brasileiro em todo o território nacional. Como Mário está menos interessado em desqualificar o português europeu para descartá-lo do que elaborar uma língua nacional que constrói a partir das expressões locais distribuídas ao longo de todo o território, parece-me mais preciso dizer que Mário promove uma hiperterritorialização da língua nacional, no sentido de que investe essa língua da autenticidade oriunda dos elementos colhidos no território nacional. 


\title{
O nó da questão
}

A noção de pequena literatura desenvolvida por Deleuze e Guattari a partir das considerações de Kafka serviu-me aqui de guia para me aproximar das obras de outros dois autores que escreveram em contextos literários também periféricos em relação ao centro da produção cultural daquele período - a França -, local bastante desdenhado por ambos os autores. A título de exemplo da estranheza que causava em seu círculo de amigos a sua rejeição pela tomada da França como lugar primeiro de referência cultural, tome-se essa divertidíssima passagem da crônica intitulada "Paris", publicada por Mário no Diário de Notícias em 31 de março de 1940:

\begin{abstract}
Digam o que quiserem, é trágico isso do artista que nunca viu Paris. Não tanto pelo beneficiamento que the poderá vir ou não dessa visita mas por essa espécie de consagração da experiência que pelo menos para nós, sofredores do complexo de inferioridade americano, nos oferece gratuitamente uma visita à capital do mundo moderno. Nos meus tempos de idealismo teorizador o simples fato de jamais ter podido visitar Paris constituiu uma verdadeira tragédia que sofri acerbamente. Vivendo entre artistas e intelectuais que conheciam Paris como a palminha das mãos e a quem o ambiente espiritual de Paris era uma força cotidiana de pensamento, foram incontáveis as vezes que tive que engolir a resposta irretorquível: 'Você nunca foi à Europa!', 'Você diz isso porque ainda não esteve em Paris!', me dava um ódio [...] Bastava algum deles ser levado à parede pela minha lógica livresca, e lá vinha a minha ignorância de Paris como argumento de salvação (Andrade, [1940] 1993, p. 170).
\end{abstract}

\section{Em paralelo, tomem-se os seguintes versos de Fernando Pessoa,} provavelmente como Álvaro de Campos ${ }^{11}$, em que paira um semelhante

\footnotetext{
11 Esse poema não foi designado a Álvaro de Campos pelo próprio Pessoa. No entanto, por coerência com as personalidades criadas pelo autor, pelo tema e pelo estilo, há na crítica um consenso quanto à atribuição desse poema a Campos (cf. Lopes in Campos, 1997 e Berardinelli in Pessoa, 1999). Teresa Rita Lopes justifica a atribuição nos seguintes termos: "Convém não perder nunca de vista que os poemas de Campos são esse 'falar alto', incoordenado como de 'um parvo que estivesse com febre' com que se apresenta nos poemas" (Lopes in Campos, 1997, p.18). Infelizmente, o manuscrito também não está datado, o que poderia sugerir que o poema fora ensejado por uma das muitas despedidas de Mário de Sá-Carneiro, amigo íntimo de Pessoa que passou os últimos anos de vida em trânsito permanente entre Lisboa e Paris, e, n'A Confissão de Lúcio, também se refere à capital francesa como "o Paris", fazendo-o, no entanto, de maneira carinhosa e não
} 
ar de desdém, acompanhado do mesmo sentimento de tédio diante da adesão generalizada à França como referência cultural:

O ter deveres, que prolixa coisa!

Agora tenho eu que estar à uma menos cinco

Na Estação do Rossio, tabuleiro superior - despedida

Do amigo que vai no 'Sud Express' de toda a gente

Para onde toda a gente vai, o Paris...

(Pessoa como Álvaro de Campos, 1997, p. 206).

É claro que as questões que estão em jogo nos três cenários (Praga em relação ao Império Áustro-Húngaro, Lisboa em relação ao Império português e o Brasil em relação a Portugal) envolvem redes de problemas específicos cuja desconsideração poria a perder precisamente a singularidade estética e histórica de cada uma dessas obras, assim como sua força política.

No entanto, utilizando a noção de pequena literatura, pouco desenvolvida por Kafka em seu diário, a partir de um aspecto central de que ela foi investida por Deleuze e Guattari, o de desterritorialização, foi possível aproximar-me desses outros dois cenários para avaliar a pertinência de pensá-la como uma categoria analítica mais ampla. Por certo, o processo de desterritorialização apontado por Deleuze e Guattari não poderia se justapor perfeitamente ao português de Portugal ou ao português brasileiro, no entanto, foi possível perceber nas obras desses dois autores, e mesmo na de Kafka, embora neste último de forma mais abstrata, uma forte relação entre a especificidade do uso da língua e sua inserção territorial, a qual se pensa menos em termos geográficos e mais em termos de pertencimento e autenticidade.

O tema da autenticidade é intrinsecamente político, na medida em que traça a linha que separa o que pertence do que não pertence, o autêntico do inautêntico. Não é de outro lugar senão do território, que se decanta o critério que orientará o lugar por onde passa essa linha de

desdenhosa, como "o meu Paris": "De novo, ungindo-me de Europa, alastrando-me da sua vibração, se encapelava dentro de mim Paris - o meu Paris, o Paris dos meus vinte e três anos..." (Sá-Carneiro, [1914] 2016, versão e-book). 
seleção. Em Kafka, tratou-se de apontar o desnível entre uma língua cartorial e a força que emana da língua efetivamente falada, o que configura um processo de dupla desterritorialização idiomática; em Pessoa, a obra crítica e a poética convergem no sentido de recolocar no centro da orientação do fazer cultural não qualquer referência externa de cultura, mas o passado daquela mesma cultura, recuperado na grandeza de tempos imemoriais e reterritorializado no cerne de uma ideia de Portugal; e, em Mário, tratou-se de plasmar na língua culta aquilo que brotava espontaneamente do falar de um povo, num processo de hiperterritorialização da língua.

Em todos os três casos, trata-se de uma discussão idiomática de implicações políticas que articula língua, povo e território. O passo decisivo de uma tal consideração da literatura é que a defesa de uma literatura não sequestrada por questões políticas, questão importante para os três autores em questão, não resulta a defesa da separação entre literatura e política ou qualquer outra dimensão social. De maneira inteiramente diversa, trata-se da defesa de uma aglutinação entre essas duas dimensões, que deve se dar sob a égide da literatura. É nos seus termos que essa imbricação deve se dar. No limite, os três autores apresentam, em projetos distintos, cada um deles formulado segundo as exigências de seus respectivos contextos culturais e políticos e por meio de formulações estilísticas particulares, uma proposta de emancipação política pela cultura.

Quer estejamos diante de uma literatura produzida a partir do uso empobrecido da língua, como é o caso da obra de Kafka, quer tenhamos uma literatura produzida em uma língua e um contexto politicamente periférico em relação à Europa, mas eivada da memória de sua própria grandeza, como é o caso da literatura de Pessoa, quer ainda estejamos diante de uma literatura produzida em um contexto politicamente periférico, culturalmente recém independente de um longo processo de colonização e defensor da construção de uma língua nova, nacionalmente constituída, como se vê em Mário, a percepção de sua pequenez política, reversivamente, enseja e alimenta um projeto de grandeza literária a ser construída e defendida em termos literários. Seu valor estilístico e sua potência política estão em 
íntima relação, de forma que a reivindicação de uma literatura formalmente elaborada pode ser tomada como uma reivindicação política, ao mesmo tempo em que torná-la visível implica, no mesmo passo, dar visibilidade ao contexto social em que ela se produziu. Daí que tal literatura implique uma necessária problematização de sua ancoragem territorial, quer essa problematização se dê pelo desnudamento de sua artificial conexão, como o faz Kafka, quer por meio de uma reafirmação, como empreende Pessoa, quer ainda como reivindicação de sua imprescindibilidade, como requer a literatura de Mário.

Em todos eles, foi possível observar a defesa da literatura como lugar capaz de fortalecer um projeto cultural de dimensões políticas, na medida em que nela se verifica a possibilidade de antecipar determinados movimentos do corpo social - como um relógio que adianta - e oferecerIhes formulação intelectual. Se a noção de pequena literatura formulada por Kafka permite, no confronto com outras literaturas produzidas em condições semelhantes, reformular-se e ajustar-se a problemas específicos de novos contextos, temos em mãos um instrumento de interrogação conjunta da cultura e da política absolutamente central para se pensar as formas de emancipação próprias daquele período. Ao fazer convergirem a produção literária e o cenário político, essa noção confere à literatura o estatuto de um ator social de extraordinária força, capaz de dar legibilidade às transformações em curso e contribuir para precipitá-las.

\section{Agradecimentos}

Agradeço aos integrantes do Seminário Temático "A Literatura na perspectiva das Ciências Sociais", em especial a Patrícia da Silva Santos e a Fernando Antonio Pinheiro Filho, reunidos no $40^{\circ}$. Encontro Anual da Anpocs, em 2016, as ricas sugestões de leitura.

Ana Lúcia Teixeira é professora de sociologia do Departamento de Ciências Sociais da Universidade Federal de São Paulo (UNIFESP) e faz parte do Comitê Científico do Research Committee "Sociology of Arts" da International Sociological Association (ISA).

Đalu.fteixeira@gmail.com 


\section{Referências}

1. ANDRADE, Mário de. O turista aprendiz. São Paulo: Duas Cidades; Secretaria da Cultura, Ciência e Tecnologia, 1976.

2. ANDRADE, Mário de. Poesias completas. São Paulo: Livraria Martins, 1979.

3. ANDRADE, Mário de. Vida literária. São Paulo: Hucitec; Edusp, 1993.

4. ANDRADE, Mário de. O movimento modernista. In: ANDRADE, Mário de. Aspectos da literatura brasileira. Belo Horizonte: Itatiaia, 2002. pp. 253-80.

5. ANDRADE, Mário de. Macunaíma - O herói sem nenhum caráter. Rio de Janeiro: Nova Fronteira, 2008.

6. BARRETO, José. A poesia política de Fernando Pessoa. Revista Abril, v. 7, n. 14, 1을 semestre, p. 189-209, 2015.

7. BLANCHOT, Maurice. De Kafka a Kafka. Paris: Gallimard, 1981.

8. BOTELHO, André. A viagem de Mário de Andrade à Amazônia: entre raízes e rotas. Revista do Instituto de Estudos Brasileiros, São Paulo, n. 57, p. 15-49, 2013.

9. BRÉCHON, Robert. Fernando Pessoa: estranho estrangeiro. Rio de Janeiro: Record, 1998.

10. CAMPOS, Álvaro de. Livro de versos. Introdução, transcrição, organização e notas de Teresa Rita Lopes. Lisboa: Referência; Editorial Estampa, 1997.

11. CARONE, Modesto. Lição de Kafka. [versão e-book]. São Paulo: Companhia das Letras, 2009.

12. CASANOVA, Pascale. A república mundial das letras. São Paulo: Estação Liberdade, 2002.

13. CASANOVA, Pascale. Kafka en colère. [versão e-book]. Paris: Seuil, 2011.

14. CATROGA, Fernando. O republicanismo em Portugal: da formação ao 5 de outubro de 1910. Alfragide: Casa das Letras, 2010.

15. CORNGOLD, Stanley. Kafka and the Dialect of Minor Literature. In: PRENDERGAST, Christopher. Debating World Literature. Londres/Nova York: Verso, 2004. pp. 272-90.

16. DELEUZE, Gilles. Critique et clinique. Paris: Les Éditions de Minuit, 1993.

17. DELEUZE, Gilles; GUATTARI, Félix. Franz Kafka: por uma literatura menor. Belo Horizonte: Autêntica, 2014.

18. DODD, Bill. The case for a political reading. In: PREECE, Julian (ed.). The Cambridge Companion to Kafka. Cambridge: Cambridge University Press, 2002. pp. 131-149. 
19. KAFKA, Franz. Franz Kafka: The Diaries (1910-1923). Editado por Max Brod. [versão e-book]. Nova York: Schocken Books, versão e-book, 1971.

20. KAFKA, Franz. Um Artista da Fome e A Construção. Atelier Paulista: São Paulo, 1984.

21. KAFKA, Franz. Tagebücher (1909-1923). Frankfurt: S. Fischer, 1997.

22. JANOUCH, Gustav. Conversations with Franz Kafka. Nova York: New Directions Paperbook, 2012.

23. LECLER, Éric. L'Absolut et la Littérature: du romantisme allemand à Kafka (pour une critique politique). Paris: Classiquer Garnier, 2013.

24. LIRA, José Tavares Correia de. Naufrágio e Galanteio: viagem, cultura e cidades em Mário de Andrade e Gilberto Freyre. Revista Brasileira de Ciências Sociais, v. 20, n. 57, p.143-209, 2005.

25. LOPEZ, Telê Ancona. "Viagens etnográficas" de Mário de Andrade. In: ANDRADE, Mário de. O turista aprendiz. São Paulo: Duas Cidades; Secretaria da Cultura, Ciência e Tecnologia, 1976. pp. 15-23.

26. MEDEIROS, Luísa. Portugal. In: MARTINS, Fernando Cabral (coord.). Dicionário de Fernando Pessoa e do modernismo portguês. Lisboa: Editorial Caminho, 2008. pp. 667-70.

27. MEDINA, João. Oh! A República! Lisboa: Instituto Nacional de Investigação Científica, 1990.

28. NEKULA, Marek. Franz Kafka and his Prague Contexts. Prague: Karolinum Press, 2016.

29. PESSOA, Fernando. Sobre Portugal. Lisboa: Ática, 1979.

30. PESSOA, Fernando. A nova poesia portuguesa no seu aspecto psicológico. In: PESSOA, F. Textos de Crítica e de Intervenção. Lisboa: Ática, [1912] 1980. p. 43-74.

31. PESSOA, Fernando. Livro do desassossego. Vol. II (Versão Integral). Campinas: Editora da UNICAMP, 1996.

32. PESSOA, Fernando. Obra em Prosa. Rio de Janeiro: Nova Aguilar, 1998.

33. PESSOA, Fernando. Poemas de Álvaro de Campos. Fixação de texto, introdução e notas de Cleonice Berardinelli. Rio de Janeiro: Nova Fronteira, 1999.

34. REIS, António; MAGALHÃES, Ana Maria; ALÇADA, Isabel. O 5 de outubro e a Primeira república. Alfragide: Caminho, 2010.

35. SÁ-CARNEIRO, Mário. Prosa Completa. Lisboa: Dom Quixote, 2016, versão e-book.

36. SEABRA, José Augusto. O heterotexto pessoano. São Paulo: Edusp; Perspectiva, 1988. 
37. SOUZA, Gilda de Mello e. O tupi e o alaúde: uma interpretação de Macunaíma. São Paulo: Duas cidades; Editora 34, 2003.

38. SPECTOR, Scott. Prague Territories: National Conflict and Cultural Innovation in Franz Kafka's Fin de Siècle. Los Angeles: University of California Press, 2000.

39. TEIXEIRA, Nuno Severino. O ultimatum inglês: política externa e política interna no Portugal de 1890. Lisboa: Alfa, 1990.

40. THIESSE, Anne-Marie. La création des identités nationales: Europe XVIIleXIXe siècle. Paris: Éditions du Seuil, 2001.

41. THIROUIN, Marie-Odile. Deleuze et Kafka: I'invention de la littérature mineure. In: GELAS, Bruno; MICOLET, Hervé (eds.). Deleuze et les écrivains. Paris: Éditions Cécile Defaut, 2007. pp. 293-310.

42. URIBE, Jorge; SEPÚLVEDA, Pedro. Sebastianismo e Quinto Império: o nacionalismo pessoano à luz de um novo corpus. Pessoa Plural, n. 1, primavera, p. 139-62, 2012.

43. WAGENBACH, Klaus. Kafka: A Life in Prague. [versão e-book]. Londres: Armchair Traveller-BookHaus, 2011.

44. ZILCOSKY, John. Kafka's Travels: Exoticism, Colonialism, and the Traffic of Writting. Nova York: Palgrave MacMillan, 2003. 